弱をみた。この結果 Data book の Broad beam による 透過率と，鉛を Chamber に密着させた值とほぼ一致し ていた。

\section{[実験 II]}

散乱線の測定. 前方散乱線については, 線源 Chamber 間距離を一定として間に鉛 Blockを入れて，乙れを 移動するととにより Chamber 鉛間の距離と線量の関係 から散乱線含有率を求めた。乙の結果鉛から $15 \mathrm{~cm}$ で約 $8 \%, 20 \mathrm{~cm}$ で約 $3 \%$.となった, 90 度方向散乱線について は，鉛 Blockを $75 \mathrm{~cm}$ のととろにおき Chamber を鉛 Block の側方に移動させ散乱線を測定した．との結果鉛 から約 $9 \mathrm{~cm}$ 離れると散乱線は殆んどなくなった。

[奏験 III]

表面線量分布の測定

鉊 Block 3, 5, 7, 9cm 亿ついて Phantom 上 $20 \mathrm{~cm}$ の 点で, Field cutしたときの表面線量の等線量曲線を描 いた。

\section{[結論]}

以上の結果から，肩胛関節部の皮膚面より $15 \mathrm{~cm} \sim 20$ $\mathrm{cm}$ 離して, 厚さ $5 \mathrm{~cm} \sim 7 \mathrm{~cm}$ の鉛 Block を使用すれば照 射線量の95\%以上を Shield できる：乙れにより皮膚及 び循環障害等の副作用を軽減するととむ可能である.

\section{買問}

垂直照射か切線照射かどちらの線量を測定したのか？ 演者が言っている鎖骨上窝部への垂直照射の防禦はわ かりますが，切線照射の場合はどうなのか，切線照射で の線量分布を実験していないのか。

多少抄録と違っていませんか。

（関西 内海）

\section{答}

この場合の鉛の厚さ，皮膚と鉛の距離及び鉛より $90^{\circ}$ 方向の散乱線と，また鉛を置いた場合の等線量曲線がど の様になったか見た．切線振子照射について問題として ない.

\section{3. 線兵分布へのリスキャン装置の応用}

横浜市大病院放射線科 （指導 伊東 乙正） 金子 世紀·君山 秀雄・佐藤長三郎 神奈川県立成人病センター 山本 洋一・梅津 幹夫

【目的〕

従来の線量分布作成には線量計および自動記録装置が 用いられている．そのため非常に労力と時間を要する. そこで我々は線量分布をカラーリスキャン装置を応用し て色彩的に表現する簡便法を試みた。
[方法]

MIXD による愿さ約 $7 \mathrm{~cm}$ の頭部, 頸部及び胸部の横 断面ファントームを各々 2 枚造り横断面に Film を挾み ${ }^{60} \mathrm{Co}$ 及び $\beta$-tron にて照射，自現機にて現像した Film を RDA-206 型走查診断装置を使用して測定を行なった。 [結果及び考察】

Film で線量測定を行なう場合問題になる事は濃度と 線量の直線性である. 特にカラーリスキャン装置を用い る場合濃度が重要とされ，そとで 7 種類の Film につい ての線量と濃度関係を調べた結果，運動照射に適した線 量及びリスキャンによる色分けに適した濃度 (0.6〜1.3) が比較的直線的関係に古る Film (Fuji lith-TAL 135) を選択した。 カラーリボンの色別は濃度の濃し方から茶, 赤, 黄, 緑, 紫, 黒, 扊色の順に 8 色儿分けら机ている. 振子照射を例にとって調べた所，線量の平均值と Film 濃度の平均值が約15〜20\%差で色別されているのが観察 できた。

従来の線量分布作成には，線量計及び自動記録装置等 が用いられているが個々の患者についての線量分布を作 製検討する事には困難を伴った。 カラーリスキャン装置 を使用すれば複雑な分布す短時間で簡単にでき而も色彩 的で見易いので治療に充分活用できる.

\section{買問}

カラーレベルを自由に変えられるか, フィルム濃度の 測定可能範用が狭いようですが，Gain 調整等で高濃度 部の測定む可能でないか.

(石川 松平)

\section{答}

カラーリボンはかえる事はできない.

\section{質問}

Rescan 装置を使用するととにより，照射から色別さ れた線量分布を得るまでに要する時間はどのくらいか。

(関西 森)

答

照射してから自現機を用いれば約30分で照射面積によ る分有表ができる。

買問

臨木的に判別能がハッキリするという点で大変よい方 式である。

（1）電子線と ${ }^{60} \mathrm{Co} \gamma$ 線を使った例を写真で見せて下 さったが，原画フィルムの比感度はどのくらいでしよう か.

（2）我々あ各例に使用出来る方法でフィルム法焼付法 を採用していますが，ファントームの制作簡易性という ことはどのような方法でやっていますか。（岩手 樋口） 


\section{答}

（1）フィルムの線質依存性は電子線， $\mathrm{Ra}, \mathrm{Co}-60$ 等で あ同一線量であれば大略同じである。

\section{追加}

スキャンニング装置を利用するために専用の濃度線量 測定装置でないために対数変換装置がついていない.そ のために使用するフィルムの広い直線性の有する物が必 要である。我々が今回入手した Gevart Dipos N51 は 濃度 $0.1 〜 4.0$ 位まで直線域で線量も $5 \mathrm{R} \sim 1,000 \mathrm{R}$ 以上ま で直線域になるので非常に有用なフィルムである.

(神奈川 山本)

\section{4. $6 \mathrm{MeV}$ リニアックの線典測定（電子線照射時の污 染X線につ(て)}

\author{
国立松山病院 \\ 小谷 富造・外河 高秋 \\ 大林 茂敏・大池 慎吾
}

リニアック電子線治療には種々の問題があり必らずし も容易ではない.電子線出力は通常の条件 ( $6 \mathrm{MeV}$ X線) では高線量率のため線量率のため線量モニターが未開発 であり，エネルギーの変換が非常に煩雑で，再現性に乏 しい. しかし，エネルギーによって治療可能範囲が定ま り，良性疾患にむ多く用いられているので污染X線量も 重要な問題である．したがって，今回はエネルギーの可 変範囲および電子線照射時の污染X線について測定した。 なお，測定法はFSD $100 \mathrm{~cm}$ で，吸収体にはアクリル樹 脂および鉛板を用い, Simplex Universal Dosimeter, Ionex Ionisation Meter および Victoreen R-Meter で 測定した。

電子線の最大最小エネルギーの測定は FS $8 \times 8 \mathrm{~cm}$ ア クリル樹脂中で測定した，最大最小エネルギーは実用上 (FSD $100 \mathrm{~cm}, 100 \mathrm{rads} / \mathrm{min}) 5.5$ および $3.3 \mathrm{MeV}$ であ り, 乙の程度の変化であれば臨床上変えて使用する必要 はない。

主ビーム中の污染 $\mathrm{X}$ 線量の測定は通常の条件でFS 10 ×10および $2.5 \phi \mathrm{cm}$ のコーンについてX線コリメータ (Jaw)を全開した時，Jaw をコーンと併用した時および Jaw を全開でコーンを取りはずした時の各々について， アクリル樹脂中， $5 \mathrm{~cm}$ より $2 \mathrm{~cm}$ 間隔で深さ $15 \mathrm{~cm}$ まで 測定した，各々の結果は指数函数曲線になり，深部 $5 \mathrm{~cm}$ で約 $0.4 \%$ 以下であった. Jaw とコーンを併用するとと により，しない時に比して污染X線量を約70\%以下に減 少できる．また，コーンでの污染 X線の発生は非常に僅 かであると考えられる.同様にして照射野外の漏洩線を 測定したところ Jaw を併用するととにより約20\%に減
少できる.

FS $6 \times 6 \mathrm{~cm}$ で污染 $\mathrm{X}$ 線の鉛での吸収曲線を求め $6 \mathrm{MeV}$ X線と比較した，約 $60 \%$ は $6 \mathrm{MeV} \mathrm{X}$ 線とほぼ同線質で あり， $40 \%$ が $6 \mathrm{MeV}$ X線の $1 / 6$ の半価首であった。

以上污染 X線とコーンの大小との関係より $40 \% の \mathrm{X}$ 線 は主として Jaw，コーン等による散乱線であり $60 \%$ D 線は Lauzl L.H. 等の阻止X線の 角度分布の近似式等か ら考慮すると殆んどビーム取り出し笎より発生したもの と考えられる.

[結論]

(1) 電子線エネルギーの可変範囲は 3.3〜 $5.5 \mathrm{MeV}$ で ある。

(2) 污染X線量は深部 $5 \mathrm{~cm}$ で主ビームの約 $0.4 \%$ 以下 である。

（3）污線X線量はX線用コリーメータを電子線用コ一 ンに併用することにより主ビーム中で約70\%に，照射野 外で約 $20 \%$ に減少できる.

(4) 污染 $\mathrm{X}$ 線量の約60\%はビーム取り出し空より発生 していると考えられる.

\section{5. $6 \mathrm{MeV}$ リナックの電子線治療に於けるガラス線量計 の利用について \\ 慶応義塾大学病院放射線技術室}

坂井 博志・荻原 淳 - 田中 幸夫

NELAC 1006 を使用して電子線治療を行なうに際し ては電子線用のモニターがないので，照射する線量を予 じめ計測した線量率を基にして時間で切る操作によって 行なっていたが，照射量に誤差を生ずる可能性がある. そこで実際に照射された線量をチェックするためにガラ ス線量計を用いてその有用性について検討した。

NELAC 1006 による電子線エネルギー 及び線量率の の安定性は照射条件を一定にした場合 $\pm 5 \%$ 以下で，エ ネルギー $-7.2 \mathrm{MeV}$ (外挿飛程 $3.4 \mathrm{gr} / \mathrm{cm}^{2}$ ), Puls 繰り 返えし数 60PPS で更も安定する．測定には

Duplex dose meter (P. T. W.)

螢光ガラス線量計 FGD-6（螢光ガラスFD-P6-3） (東芝製)

を使用した。

測定に使用した螢光ガラスの精度は50個のガラスに一 定量の ${ }^{60} \mathrm{Co} \quad r$ 線を当て個々のバラッキを調べた結果士 2\%以下であった.

この螢光ガラスの電子線曝射による螢光量 $(\mu \mathrm{A})$ に対 して電子線量は $0 \sim 4,000 “ R ” の$ 間に直線性が認められた。 この螢光ガラスを ${ }^{60} \mathrm{Co} \gamma$ 線によって較正して得た較 正係数は 